\title{
Communicative Planning As Institutional Capacity Building: From Discourse/Network To Opportunity
}

\author{
Delik Hudalah ${ }^{1}$ \\ Diterima : 9 Agustus 2012 Disetujui: 5 Januari 2013
}

\begin{abstract}
Abstrak:Makalah ini berupaya meredefinisi ide-ide tentang perencanaan komunikatif tidak hanya sebagai praktek partisipatif dan demokratis tetapi juga sebagai bentuk pengembangan kapasitas kelembagaan yang berorientasi pada perbaikan ketatapemerintahan. Selama ini pengembangan kapasitas terfokus pada eksploitasi sumberdaya sosial yang bersifat internal bagi aktor, yaitu melalui pengembangan pengetahuan (argumentasi, debat, pewacanaan dsb) dan relasi sosial (jejaring, koalisi/aliansidsb). Makalah ini berargumen bahwa dalam persoalan perencanaan yang sangat kompleks yang ditandai dengan fragmentasi dan ketidakpastian sistem kelembagaan, sumberdaya sosial yang bersifat internal tersebut perlu dikawinkan dengan eksplorasi sumberdaya yang bersifat eksternal, yaitu struktur dan momentum peluang. Hasil analisis menunjukkan bahwa kinerja pengembangan kapasitas kelembagaan dalam proses pengambilan keputusan komunikatif dapat dilihat pada tiga aspek: pelibatan aktor secara strategis dan inklusif, meningkatnya perhatian aktor terhadap isu dan agenda perencanaan penting yang sering terabaikan, dan konsistensi dan kesadaran untuk melaksanakan ide, kerangka dan keputusan yang telah disetujui.
\end{abstract}

Katakunci: pengembangan kapasitas, peluang, wacana, jejaring

\begin{abstract}
The paper redefines the ideas about communicative planning as not only participatory and democratic practice but also capacity building oriented toward the improvement of governance styles and consciousness. So far capacity building has focused on the exploitation of social resources internal to actors. These internal resources include knowledge (argumentation, debate, discourse formation etc) and relational (network, coalition, alliance etc) building. The paper argues that in dealing with very complex planning problems characterized by fragmented and uncertain institutional systems, the internal resources need to be coupled with the exploration of resources external to actors, namely the political opportunity structure and moment of opportunity. The analysis implies that the performance of communicative decision-making process as capacity building can be assessed in three aspects: strategic and inclusive actors' involvement, the building of actors' awareness on neglected but important planning issues and agendas, and consistency and deliberation in realizing and delivering agreed planning ideas, frameworks and decisions.
\end{abstract}

Keywords: institution/capacity building, opportunity, discourse, network ${ }^{1}$ School of Architecture, Planning, and Policy Development, InstitutTeknologi Bandung
Labtek IX-A $2^{\text {nd }}$ Floor, Jl. Ganesha 10, Bandung 40132

Korespondensi: d.hudalah@sappk.itb.ac.id 


\section{Introduction}

Key planning issues that should be dealt with by contemporary Indonesian planners have been related to the acute clientelist governance culture, fragmentation and the increasing influence of global neo-liberal development ideology (Hudalah, Winarso, \& Woltjer, 2007; Hudalah \& Woltjer, 2007). These issues require planning to put more attention upon implementation, execution and realization rather than on plan formulation aspects. It is argued that a large part of planning implementation issues can be addressed by focusing on the political dimensions of planning, including organizational and institutional aspects (Alexander, 2005; F. Fischer, Forester, Fischer, \& Forester, 1993a; Hajer, Brink, \&Metze, 2006; Healey, 1999; Lees, 2004). As such, any research focused on the application of institutional approaches may contribute in bridging the gap between plan-making and its implementation.

The application of sociological institutional approaches in planning has so far emphasized the role of social resources internal to actors, especially in the forms of discourse and network, as a means of building institutional capacity (Gualini, 2001; Healey, 1998; Rydin, 1999; Vigar, Healey, Hull, \& Davoudi, 2000). This agency-centered sociological approach has been criticized for giving inadequate accounts on the role of contextual forces such as the economy, power relations and the state (Huxley \& Yiftachel, 2000; P. M. McGuirk, 2001; Tewdwr-Jones \& Allmendinger, 1999). As a response, this paper willemphasize that discourse and network need to be coupled with moment and structure of opportunity, as a key resource external to actors.

Using the sociological institutional approach, this paper willextent ideas in communicative planning approaches by focusing on the building of institutional capacity. Particularly, it will compare and combine discourse, network and opportunity approaches as aspects in institutional capacity building. Institutional capacity here is defined as the ability of governance to promote social acceptance and legitimacy of planning ideas, strategies, frameworks, and action. The main proposition is that, in the face of fragmented institutional arrangements - as mostly faced by ordinary planners in Indonesia, the building of such capacity can be started from informal day-to-day practices of governance process, including the building of policy network, discourse formation and the exploration of moment and structure of opportunity.

Our theoretical discussion will be structured as follows. First, the main theoretical foundation of institutional approaches is compared from which the sociological approach is selected as the basis for our further discussion. The planning theoretical discussion is then divided into three key concepts/aspects of our then-so-called institutional capacity building: discourse, network and opportunity. The concluding section outlines some propositions regarding planning as institutional capacity building.

\section{Institutional approaches and planning theory}

One of the key issues in planning is how to deal with plural, irresponsive and fragmented institutional arrangements hampering the achievement of sustainability objectives. Major new institutional and planning theoretical approaches have the potential to be able to address such institutional/contextual issues, including rational institutional approach, historical institutional approach and sociological institutional approach.

First, the rational institutional approach focuses on human instrumental behavior aspects based on strategic calculation in which individuals seek to maximize the attainment of preferred goals (Hall \& Taylor, 1996). Institutions affect behavior by providing certainty about the behavior of other actors. In this approach, institutions are defined as the 'rules of the game' by which agency/action is enabled and constrained. Institutions are seen as an 
instrument to enhance the efficiency of action by reducing transaction costs of undertaking the same action without such an institution (Hall \& Taylor, 1996). Planning's application of this approach has focused on institutional design, referring to 'the devising and realization of rules, procedures, and organizational structures that will enable and constrain behavior and action so as to accord with held values, achieve desired objectives, or execute given tasks' (Alexander, 2005, p. 213). It is essentially a technical, purposive, and experimental process of designing institutional arrangements (Bolan, Mandelbaum, Mazza, \& Burchell, 1996; Gualini, 2001). As another application, Sager (Frank Fischer, Forester, Fischer, \& Forester, 1993b; 1995) uses social choice theory to explain the relation between types of planning styles and organizational contexts in which planning is practiced. The main weaknesses of applying such a rational approach are due to taking the institution out of its context. The approach treats institution as external to action thus simplifying and reducing the ambiguity and complexity of human motivation and preference into sets of predefined rules, procedures, and organizational structures (Hall \& Taylor, 1996).

In the historical institutional approach, institutions are defined both as 'formal and informal procedures, routines, norms, and conventions embedded in the organizational structure of the polity or political economy' (Hall \& Taylor, 1996, p. 938). Institutions are associated with organizations, rules, and conventions promulgated by formal organization. The approach emphasizes institutions as unintended consequences of history, path dependence and uneven power relation and distribution.

The historical institutional approach has played a significant role in some variants of postmodern planning approaches, in which planning is seen as a 'struggle for power' in the context of politically rationalised institutions (Flyvbjerg, 1998; Huxley \& Yiftachel, 2000; P. M. McGuirk, 2001). The problem with this approach is apparent in its structural analytical perspective. First, the approach tends to overstate the uniqueness of particular cases and contexts thus compromising its contribution to general theoretical building (Immergut, 1998). Furthermore, it treats the institutions prevailing in that particular case as an external, given and passive factor for planning action thus lacking normative and practical implications (Rydin, 2003).

Anticipating the weaknesses of both rational and historical approaches, as an alternative, the current paper is built on the sociological institutional approach. According to this approach, institutions share meaning with 'culture', comprising 'not just formal rules, procedures, and norms, but the routines, symbols, cognitive scripts, and moral templates that provide the "frames of meaning" guiding human action' (Hall \& Taylor, 1996, p. 947). Institutions function not just to reduce transaction costs (rational institutional approach) or to give context (historical institutional approach) but also to build social legitimacy of action (W. W. Powell \& DiMaggio, 1991).

The sociological institutional approach emphasizes an interactive and mutuallyconstitutive relationship between institutions (structure) and action (agency) (Giddens, 1986). It is a process-oriented view on institutions in which, according to Powell and DiMaggio (1991, p. 7), institutions 'do not merely reflect the preferences and power of the units constituting them; the institutions themselves shape those preferences and that power'. Following this, the notion of institutions, institutional change and institutional transformation fundamentally shifts their focus from formal organizations towards informal rule-like forms of institutions; from static and stable to dynamic and contesting characters of institutions; from holistic to incremental institutional change; and from top-down, independent and hierarchical to bottom-up, embedded and relational institutional formation (Lowndes, 2001). 


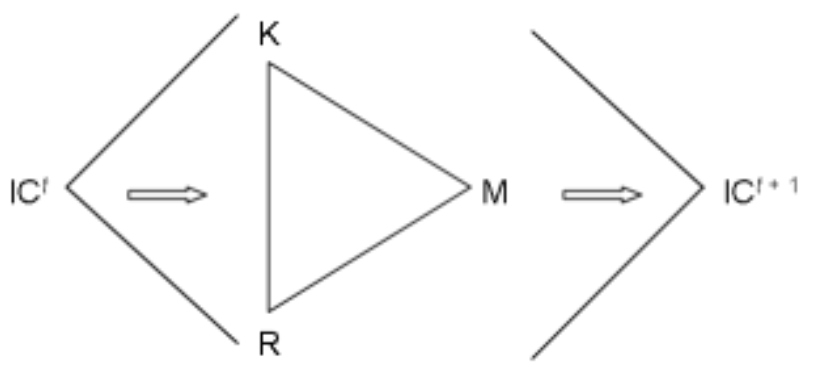

IC = institutional capacity

$\mathrm{K}=$ knowledge resources

$\mathrm{R}=$ relational resources

$\mathrm{M}=$ capacity for mobilization

(source: Healey, 1998, p. 1541)

Figure 1 Institutional capacity building as a function of knowledge and relational resources

Planning's application of the sociological institutional approach has concentrated on institution building, referring to a gradual and socially constructed ethos of transforming institutional aspects that affects the nature of planning policy space (Gualini, 2001). According to Gualini(2001), the process involves mobilizing and pursuing shared commitment, contingent unity of meanings, and constitution of collective actions. As can be seen in Figure 1, in Healey's collaborative planning, emphasis has been given to the notion of discourse (knowledge resources) and policy network (relational resources) as two important mobilizing aspects of "building an institutional capacity focused on enhancing the ability of place-focused stakeholders to improve their power to "make a difference" to qualities of their place' (Healey, 1998, p. 1541, emphasis added).

However, in Healey's later works (Coaffee \& Healey, 2003; Gonzal,z \& Healey, 2005; Healey, 2007a, 2007b), it becomes apparent that discourse and policy network per se hardly result in successful institutional capacity building. Therefore, in order to overcome this weakness, the paper will propose a combination of discourse and network, as the main resources internal to actors, with the moment and structure of opportunity, as the main resource external to actors. The opportunity enables the actors to read cracks in power relations, to recognize contradictions and conflicts, which encourages these actors to realize that they need to reflect on what they are doing, that they need to work with others, and that they need to evolve different processes (Healey, 1997). More specifically, by employing the idea of moment and structure of opportunity into the existing framework, the current paper attempts to maintain the normative dimension of Healey's institutional capacity building while strengthening its contextual intelligence.

\section{Discourse as a Knowledge Resource}

In the last decades, discourse analysis and theory has influenced the development of post-positivist urban planning theory. First, discourses can be seen as a descriptive analytical approach to explain the influences of power and social structures on planning (Richardson, 2002). Besides, discourses have been utilized as a normative strategy for communicative planning (Healey, 1997). Enhancing the latter idea, this paper develops on the institutional dimensions of discourses; on how discourses connect planning ideas to their social contexts (Vigar et al., 2000). As such, discourses may influence a planning process by framing the ways in which agendas are set, issues are defined, problems are understood and possible solutions are delimited (Rydin, 1999). 
Discourse can be defined as sets of ideas and concepts that are reproduced in daily processes of a policy practice (Hajer, 1995). It is constituted by sets of arguments, myths, metaphors or phrases, which are transformed into more acceptable forms of policy language. Discourses play a role in giving meaning to the complex interactions of material and social realities. Nevertheless, the accurate relation between discourses and realities is still contested. From postmodern approaches, discourses or language structures in general, are perceived to represent, and thus to be inseparable from, the realities themselves (Richardson, 2002). The approaches are influenced by Foucault $(1971,1978)$ who views power as the pervasive aspect of societal reality whose exercise is represented through discourse. Alternatively, discourses can be perceived normatively as a communicative strategy of using and manipulating realities to promote particular agendas. Extending the latter idea, discourses are regarded rather as a medium for making sense of the invisible structures of the realities (Vigar et al., 2000).

Discourse is an alternative approach through which we can comprehend how new institutionalism works in practice. Discourses essentially have institutional dimensions, implying not just substantial knowledge but institutional structure containing internal rules that frame action (Hajer, 1995). The meanings that discourses carry are also more than just linguistic structures, which are often static and uncontextualized. Discourses also contain social framework creating conditions for our thought, communication and even action (Richardson, 2002; Vigar et al., 2000).

The most essential concept of discourse approach for policy practices is probably discourse formation or 'doing discourse', referring to the borrowing, adaptation, transformation and/or reproduction of discourse by particular policy communities for particular policy audiences situated in particular institutional contexts. It can be a reflective, and not linear, process and, according to Hajer(1995), it takes place at several levels of institutionalization. In the first level, sets of ideas, which are grounded in particular social relations, are structured into coherent story-lines. Following this structuring process, the story-lines are communicated, merged, and consolidated by networks of policy communities so they become embedded within daily policy practices.

The adoption of discourse formation in planning and urban studies has followed two major approaches (Lees, 2004). The first approach is based on Foucault's works, which explains that discourse production is a process of selection through the mechanisms of societal exclusion, prohibition and constraint (Foucault, 1971). Following this, in planning practice, discourses are seen as an unintended phenomenon, mainly reproduced as consequences of constant political struggle for urban spaces (Richardson \& Jensen, 2003). Such discourses function to provide constraining conditions for planning practice.

Using the Foucauldian approach, Richardson (2002) shows that discourses can explain the political context for planning process. It is based on the assumptions that planning is situated within a complex discursive environment in which the relation between discourse, power, and knowledge is highly apparent (Flyvbjerg, 1998). It is argued that 'language, and how it is reproduced in different places, is of critical importance in shaping events in the world, and certain languages can reinforce power structures' (Richardson, 2002, p. 353). By using this perception, planning is seen as 'an arena of constant struggle over meanings and values in society, played out in day-to-day micro level practices of planning' in which discourse is 'an element of both critical analysis and reflexive practice in planning' (Richardson, 2002, p. 353).

The adoption of Foucauldian approach into planning entails several weaknesses. As Richardson (2002) stresses, only the wider institutional environment can reproduce and control discourses through systematic exclusion of creating prohibitions, taboos and rationality attributes. The approach leaves almost no room for a planning agency to play a pro-active role in the process of discourse formation. Besides, since discourse is seen as an 
explanatory mechanism, this approach, as Richardson (2002) observes, cannot provide any prescriptive dimension for planning action. Further critiques are the results of the inherent limitations of Foucauldian approaches, including their oppressiveness, relational power neglect and demystication of the meaning of rationality (Rydin, 2003).

As an alternative, communicative approach argue that discourses can be proactively reproduced by policy communities as a purposive strategy for promoting planning agendas (Healey, 1997). Further development of this approach tends to perceive planning discourses as a result of complex interactions between groups of policy communities, as discourses reproducers, and their institutional contexts (Healey, 1999; Rydin, 2003).

Drawing on communicative approaches, Throgmorton(1992) introduced discourses in the form of narratives about the future that can be used by planners to persuade actors' attention on the proposed ideas. Healey $(1997,1998)$ and Innes \&Booher(1999) also frequently point out that argumentative practices in general and discourse formation in particular are an essential aspect of collaborative planning. Here discourses are considered purposive, argumentative and persuasive systems of meaning embedded in strategies for action. Discourses are produced proactively by groups of planning communities around planning issues through communicative actions.

Giving more emphasis on the potential of action, the communicative approaches, and thus their purposive discursive approach, are considered to provide a limited account on the roles of institutional settings as reflected in the state, the economy and relational power (Tewdwr-Jones \& Allmendinger, 1999). To overcome this limitation, Rydin(1999) proposes that discourses need to be better linked contingently into the wider institutional structure in which they are situated. As such, discourses, constituted by linguistic as well as broader social resources, can bridge the structure-agency duality. Incorporating new institutionalism, here Rydin(2003) tries to create a balanced position where discourses are seen as structurally constrained as well as purposively constructed institutional software. Discourses tend to be perceived as an emergent social phenomenon, whose reproduction is contingent, incomplete and engaged with complex governance contexts (Healey, 2007a).

In the light of new institutionalism, discourses have the ability to translate ideas and concepts that are acceptable in the policy realm into linguistic and, furthermore, broader socio-cultural structures. Doing discourse formation, we actually use, engage with as well as reshape those structures in order to reconstruct the frame of reference for socially legitimate planning action. As Vigaret al(2000, p. 223) argues:

'Policy discourses provide a language of representation - of space and place, of local environments, of sociospatial arrangements and policy processes - which can provide powerful images with a capacity to convince, to disseminate widely and become key "referents" in subsequent policy debate ... Where power was distributed among diverse agencies and loci of legitimacy, the capacity to persuade became a key quality of effective urban and regional policies'.

The ultimate goal of discourse formation, as an important aspect of institutional capacity building, is thus not merely imposing a planning proposal but contributing to the transformation of governance attitudes that hinder socially innovative ideas and action, which tend to come from outside formal processes (Healey, 2007a; Rydin, 1999).

In order to open up innovative, hidden and marginalized issues, Rydin(1999) suggests that institutional discourses need to be inclusively managed and positively 'manipulated'. Discourse management helps to identify potential common sense as the basis for action. It also can transform unnecessary conflicts into consensual images as a precondition for socially legitimate action. In addition to bringing formally invisible issues to the table, wellmanaged discourses also can fold fragmented practices into stronger coalitions (Rydin, 2003). 


\section{Network as a Relational Resource}

A (social) network can be broadly defined as 'a regular set of contacts or social connections among individuals or groups' (M. Granovetter \& Swedberg, 2001, p. 11). With this broad definition, networks, particularly in sociological economics, may refer to all kinds of social relations (Yeung, 1994). However, this paper restricts the scope of enquiry to a comparison of their unique characteristics with the characteristics of other major forms of social relations, especially markets and hierarchies.

Powell (1991) identifies these unique characteristics as follows. First, networks emphasize horizontal and decentralized - rather than hierarchical and centralized - social relations as they bring together actors of relatively equivalent role and status. These networks are typified by informal, implicit and reciprocal - instead of transactional (in markets) or employment (in hierarchies) - patterns of communication and exchanges. They promote interdependent - as opposed to independent (in markets) and dependent (in hierarchies) - relationships among actors. Another important feature is that networks imply moderately flexible relationships. These networks produce enduring but rather 'loose coupling' relationships. Such relationships preserve the autonomy of connected actors and prevent them from being 'locked into' specific rigid relationships (Grabher, 1993a).

By comparison, rational planning literature on social relations has emphasizedhierarchical organizational arrangements as a means of reducing transactional costs resulting from the gap between the planning formulation process and the complexity of its implementation (Alexander, 1993). Fundamental shifts of attention in the literature towards network forms of social relations did not appear until the rise of the issue of social and political fragmentation, which increasingly characterizes planning in the informational and globalised society (Healey, 1997). From a systemic viewpoint, for example, networks are defined as open, dynamic and self-organizing social systems taking the form of sets of interconnected actors with certain communicative codes, values or goals. This form of network is later adopted in communicative planning as a medium of spreading 'informational power' in collaborative processes (Booher \& Innes, 2002). Yet, this informational perspective on networks still maintains the rationalistic view as it assumes the pre-existence of universal and perfect diversity, interdependence and mutual dialogue among participating actors. These assumptions are hardly evident in the social relations that have been unequally bounded by fragmented socio-cultural and institutional contexts. In short, this idealistic viewpoint hardly takes power as well as institutional/governance dimensions into account in planning practice. For this reason, some scholars have suggested treating networks under more structural theories such as regulation theory, Bourdieu's theory (Moulaert \& Cabaret, 2006) and the Latourian approach (Pauline M. McGuirk, 2000). The problem with this approach is, since its analysis tends to be structural and historical, that it results in descriptive, if not destructive, suggestions, providing very limited opportunities for agency to reconstruct the networks. As an alternative, this paper argues that new institutionalism in sociology can more effectively address the governance inadequacies that often typify the planning processes on the edge of cities in developing and transitional democratic countries.

From this sociological perspective, which was later adopted in regional economics, the institutional dimensions of networks can be explained through the concepts of social capital, embeddedness and/or institutional thickness. First, as a process in the building of social capital, networking may take a considerable social construction effort in the forms of enduring interdependent and reciprocal relationships (Putnam, 1993). Networks do not guarantee that actors attain tangible and short-term objectives but rather provide them with a reputational, taken-for-granted and cultural frame of reference that constrains as well as enables their action. As an alternative explanation, if a firm (or an actor in the broadest sense) is embedded within a network, its action and opportunities are shaped by this social 
relationship and, thus, its motivation moves away from the narrow pursuit of profit (or other short-term, tangible and material) gains towards the enrichment of this relationship through trust and reciprocity (Uzzi, 1996). In another conceptual understanding, if a given region (or a society) has a 'thick' network form of social relations, there may be high levels of contacts, cooperation and interchanges embodied in shared rules, conventions, and knowledge which serve to constitute a supporting contextual environment for regional development (or social progress) (Amin \& Thrift, 1994). In short, these three overlapping concepts lead us towards the perception that networks can be regarded as a form of institution and, accordingly, networking can be seen as an important aspect of institution building.

Networks have the ability not merely to channel shared (informational) power but moreover to function as institutions. As Castell (2003, p. 427) concludes, 'these networks do more than organizing activity and sharing information. They are the actual producers, and distributors, of cultural codes', which may construct new institutions. In explaining this argument, transactional and historical institutionalism has focused on the reasons how the existence of such networks may increase the potential costs for opportunist action and manifest past success in collaborative action (Putnam, 1993). Meanwhile, sociological institutionalism, as far as the current discussion is concerned, moves away from this preexistent feature and predefined functions of networks towards its reflexive construction and framing functions.

Studies in sociology and regional economics show that the constructed networks can transform into those functioning as institutional reference gaining the capacity to frame action. First, Granovetter(1973) describes the unique capacity of these networks through the concept of 'weak ties', referring to ideal open, horizontal, informal network forms of social relations. Weak ties tend to link weak groups of actors rather than strong ones. Different and fragmented strong ties are not linked altogether but bridged through indirect contacts promoted by these weak ties. This contextual richness of weak ties builds a cohesive community thus collaborative action more likely to happen (M. S. Granovetter, 1973). Furthermore, the 'loosely coupled' relationships promoted by networks combine this contextual richness with a degree of flexibility. Both unique features may increase the ability of networks to learn and change (Amin \& Thrift, 1994). This learning capacity is required to produce innovative social action. These combined features also facilitate the construction as well as mobilization of knowledge. It is argued that the knowledge passed through networks is relatively 'freer' than that which flows in formal organizational hierarchies and 'thicker' than that captured through independent external resources (Grabher, 1993b).

\section{Opportunity as an External Resource}

The concept of opportunity has been developed in at least two disciplines: social movement and public policy. First, in social movement theory, opportunity concernsthe relationship between a group that acts collectively and the contextual environment around it (Tilly, 1978). It generally refers to constraints, possibilities, and threats originating outside the group, but affecting its chances for successful collective action (Koopmans, 1999).

The theoretical development of opportunity as a social movement approach has largely concentrated on the concept of political opportunity structure. Tarrow(1994, p. 18) defines this structure as 'consistent - but not necessarily formal, permanent, or national dimensions of the political environment which either encourage or discourage people from using collective action'. The main resources of opportunity are the state's political system, political allies and political elites. Tarrow(1994) argues that opportunity for state-wide protests, lobbying or other forms of social movements in a particular country appears if the state's system changes, influential allies shift or arise, or elites conflict with each other. 
The concept of political opportunity structure has been used to explain the surge and decline of various civil rights movements, the peace, environmental and feminist movements, and national revolutions in modern history all over the world (Tarrow, 1994). This structural approach has also been used for cross-national comparisons of mobilization patterns, strategies and impacts of anti-nuclear movements (Kitschelt, 1986) and ecological, solidarity and peace movements (Kriesi, 1992) in Western Europe.

Political opportunity structure has been able to provide historical explanation on how opportunities evolve and shape collective action. Nonetheless, it can be criticized for focusing on the political aspect as the main resource of opportunity whereas social movement and other forms of collective action may also be influenced by economic, cultural and other broader societal aspects. Although the concept provides a powerful approach for geographical comparisons, it is less helpful in explaining variations over time (Koopmans, 1999). Meanwhile, it is argued that changing structures within a place are more important to open the gates of opportunity than the static differences between different places (Tarrow, 1996).

The dynamics of opportunity can be better observed by using Kingdon's policy window framework. Applying the bounded rationality of the garbage can model (Cohen, March, \& Olsen, 1972), Kingdon's framework introduces the logic of time as a unique and scarce resource for promoting policy changes. The framework was originally used to explain the evolution of health and transportation policies in the federal government of the United States (Kingdon, 1984). The strength of this framework lies in its ability to explain how policy agendas and alternatives are chosen under conditions of ambiguity by assuming a temporal order in which the adoption of specific policy alternatives is dependent on when policies are made (Zahariadis, 1999).

Central to Kingdon's idea is the role of multiple streams and coupling (Zahariadis, 1999). There are three separate streams flowing through policy systems: problems, policies, and politics. Each stream is relatively independent of the other with its own dynamics and rules. Policy windows function as moments of opportunity for policy entrepreneurs to couple all the three streams together (Kingdon, 1984). The windows are opened by dramatic changes in problem and/or political streams, for instance, disasters, crises, policy implementation feedbacks, swings in national mood, elections, changes of administration and pressures from interest groups. The coupling can dramatically enhance the chances for the proposals flowing in the policy stream to receive serious attention from policymakers.

In comparison, the political opportunity structure sharpens the meaning of geographical variations as a relatively stable context for social movement whereas the policy window stresses the unique role of time as a dynamic resource in the policy process. Both approaches emphasize opportunities as spatial and temporal resources external to actors, namely, contextual factors working beyond the control of participating actors. The approaches currently may be helpful in explaining how and when critical situations come about, but they cannot sufficiently suggest how actors can make, prolong or extend them (Gamson, 1996; Koopmans, 1999).

Furthermore, applying the political opportunity structure approach directly to environmental planning conflicts might be problematic. First, the problems are not as structured or as radical as that in most social movements but they are more dynamic and flexible. Moments of opportunities in environmental planning conflicts are also more complex than policy windows because the three streams cannot be simply restricted and isolated but are evolving and interlinked with each other. In addition, capacity building in environmental planning entails not just pursuing short-term common political interests or policy proposals but also contributing to gradual transformation of governance practices and consciousness. 
In order to provide more room for actors and to further solve the planning application problem identified in the preceding, this paper considers an integration of the two existing approaches with the sociological institutionalism. The sociological institutional thinking has increasingly influenced the theoretical development of the political opportunity structure and the policy windows. It is suggested that the policy windows do not just constrain but guide and give meaning to action (Zahariadis, 1999). Furthermore, the opportunities may provide an interactive link between structure and agency (Koopmans, 1999). They are not necessarily passive and structured since people actively construct them. In fact, according to Gamson(1996, p. 276), opportunities are contestable, vulnerable, often representing 'a locus of potential struggle, not a leaden reality to which we all must inevitably yield'. This thinking implies that the concept of opportunity should shift its attention from comparative and state-centered analysis towards dynamic and agency-centered analysis.

Such thinking implies that the concept of opportunity should shift its attention from comparative and state-centered analysis toward dynamic and agency-centred analysis. It is not the opportunities per se but the actors who 'do the work' (Lowndes, 2005). Opportunities need to be framed and mobilised in order to be able to function as an effective resource for institution building (Gamson, 1996). The historical, political and structural dimension of opportunity needs to be linked with discursive, cultural, and relational resources that are more embedded in the daily life of participating actors (Koopmans, 1999). In Tarrow's typology of the political opportunity structure, this variant might be close to 'group-specific opportunities', focusing on how specific groups mobilize and extend their knowledge and relational resources by linking them with emerging opportunities that shift over time (Tarrow, 1996).

Based on these theoretical arguments, this paperproposes the combination of the political opportunity structure and the policy window framework under the umbrella of the sociological institutionalism. It particularly attempts to retain the strengths of spatial and temporal factors provided by the two established approaches. These external factors are represented by the structure of opportunity and the moment of opportunity respectively. The former represents relatively consistent, stable factors such as national political system and domestic political culture whereas the latter refers to dynamic, less predictable, emerging factors such as catastrophic events and opponents' decision and action. In addition to these contextual factors, knowledge and relational resources are treated as key factors internal to actors that play a proactive role in exploring, capturing, and translating the external factors into powerful opportunities.

Related studies have shown us that the collective process of constructing structures and moments of opportunity carries several aspects of institutional capacity building. The first aspect can be seen in how, in collective action, opportunities co-evolve with mobilization of knowledge and relational resources. First, opportunities trigger an innovative mobilization of these resources. As Healey (1997) argues, moments of opportunity represent a crack in power relations or a situation of contradiction and conflict. Such critical situations encourage people to recognize that they need to work with different people (to build relational capacity)and to evolve different arguments (to build knowledge capacity). On the other hand, mobilization of discourses and organizational networks builds new strategies and influences others to respond or participate thus expanding groups' opportunities (Tarrow, 1996). While the structures and moments of opportunities play as the external factor, in our framework, the knowledge and relational resources are treated as key factors internal to actors that play a proactive role in exploring, capturing, and translating the external factors into powerful opportunities.

As another aspect of capacity building, opportunities also imply more institutional space and fewer constraints thus empowering structurally weak and disorganised groups to 
participate (Gamson, 1996). The emergence of opportunities opens the possibility for the resource-poor entities to better contribute in institution building.

Finally, the constructed opportunities help establish priority (Kingdon, 1984) and raise actors' awareness on particular policy issues. In this respect, opportunities act as an 'attractor' that focuses actors' attention on the issues in the conflicts.

\section{Some Propositionsand Assessment Criteria for Capacity Building}

Guided by sociological institutionalism, we have explored the potential of network, discourse and opportunity in producing innovative planning approaches. Historical institutionalism, Foucauldian approaches and post-modern planning theories have long emphasized the structural formation of policy network, discourse andopportunity (Flyvbjerg, 1998; Huxley \& Yiftachel, 2000; Immergut, 1998; P. M. McGuirk, 2001). Meanwhile, our analysisproposes that network, discourse and opportunity are not necessarily structured by history but, at the same time, they can bereconstructed by the actors throughout planning and governance processes. For example, the debates on the Dago-Lembang road development and Punclut could not instantly become important moments for building awareness on preserving NBA but committed environmental advocates and planners actively reconstructed meanings out of these perceived moments(Hudalah, Winarso, \& Woltjer, forthcoming-a). Although they might have different motivations, they were connected with each other by shared common objectives: to improve planning's institutional capacity in NBA. The process was expanded by means of discourses and networks(Hudalah, Winarso, \& Woltjer, forthcoming-b; Hudalah \& Woltjer, 2009). While actors' motivation functioned to fuel the capacity-building process, discourses and networks provided the infrastructure to reach the capacity-building objectives.

Policy networking, discourse formation and opportunity making function not only to resolve conflicts but also to contribute to the building of institutional capacity. The notion of institutional capacity implies the ability of governance not to merely reduce unnecessary transaction costs or constrain undesirable actions but, more importantly, to promote social acceptance and legitimacy of emerging, innovative planning ideas, strategies, frameworks, and action. Moreover, the focus on opportunity, network and discourse implies that the building of institutional capacity does not always start from the formal planning process set up by the government and professional planners but can emerge from informal day-to-day practices involving wider participants outside the formal planning community.

As illustrated by Figure 1, past studies have been inclined to emphasize the building of institutional capacity as mobilization of discourse and policy network as the main resources internal to agency's action (Gualini, 2001; Healey, 1998; Rydin, 2003; Vigar et al., 2000). Meanwhile, our discussionproposes that in order to make institutional capacity building work, it is likely thatthe internal resources in the forms of discourse and policy network need to be coupled with moment and structure of opportunity as a resource external to actors (Figure 2). Such coupling may be able to reinforce the earlier agencycentered approach, which has been criticized for its limited attention on the role of broader institutional settings reflected in the state, the economy and power (Huxley \& Yiftachel, 2000; P. M. McGuirk, 2001; Tewdwr-Jones \& Allmendinger, 1999).

A clear example of this coupling would be the urban environmental discoursecoalition in the Punclut project and the environmental policy network in the DagoLembang project(Hudalah et al., forthcoming-a). The network and coalition were able to minimize or to marginalize the growth coalition hegemony by exploring strategic moments such as debate escalation on protecting the water recharge area, shifts in societal moods (growing societal interests on quality of life and regional sustainability) and natural disasters (floods affecting the city, landslides in peri-urban areas). In addition, they also drew on the political structures in the forms of local and regional elections, local and 
regional political coalitions, elites' constellations, government organizational structure, and the institutional arrangements of Indonesia's democratic society.

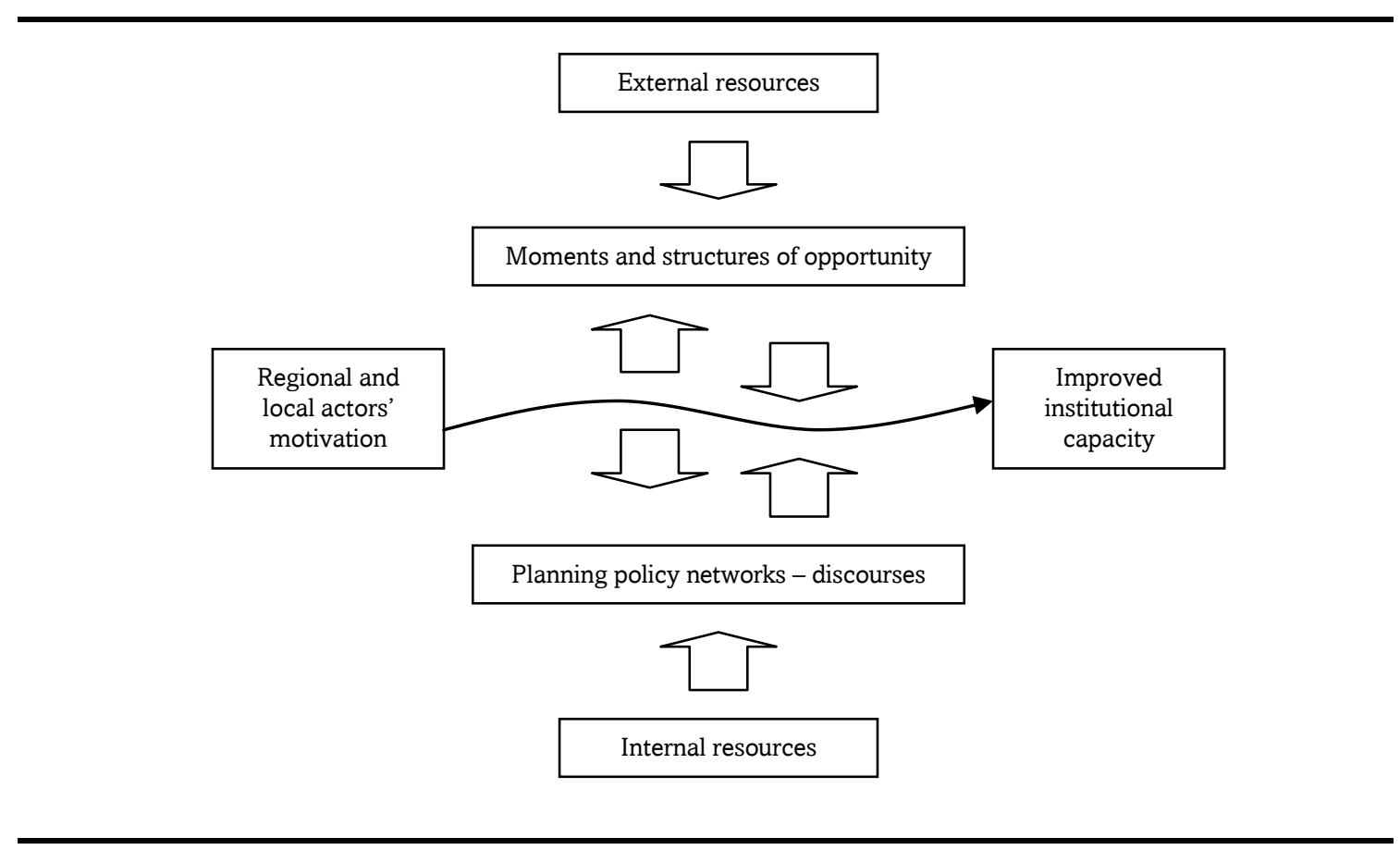

Figure 2 An Institutional Capacity-Building Process

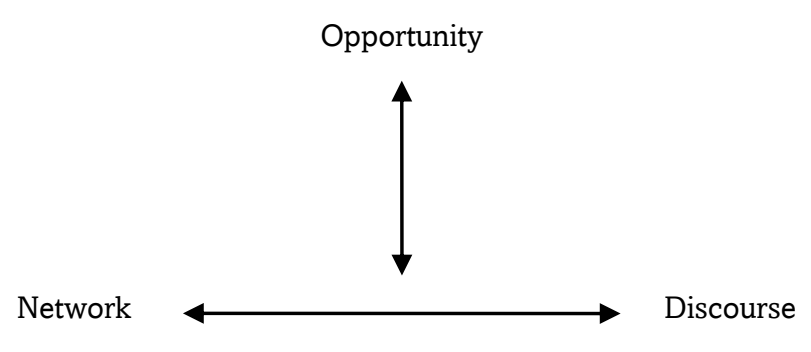

Figure 3 The Interactive Relationship Between Opportunity, Network And Discourse In Institutional Capacity Building

Network, discourse and opportunity strategies function in support with - rather than as substitutes of - each other in managing conflicts and building institutional capacity(

Figure 3). First, the opportunities helped to mobilize discourse and policy network as relational and knowledge resources for collective action. This was particularly reflected in the development of an environmental policy network in the Dago-Lembangproject and the formation of water recharge discourse in the Punclutproject. In the former, the network was used as an 'infrastructure' through which the discourse of preserving the ecological functions of NBA was constructed and mobilized. In a similar fashion, in the latter, the 
'water recharge discourse also provided an innovative reasoning for wider marginalized actors to join in with and reinforce the complex network of environment-concerned communities. This relational building is clearly evident in the evolution of GALIB/KMBB.

In the context of the open, democratic and fragmented Indonesian society, the contribution of network, discourse and opportunity to the building of governance capacity can be assessed according to three criteria:

1) Strategic inclusion: network, discourse and opportunity should be able to involve stakeholders as strategically (corporatist) and as inclusively as possible in the decisionmaking process.

2) Facilitation of the weak: network, discourse and opportunity should be able to raise, accommodate, focus and channel stakeholders' awareness on important yet neglected issues and agendas.

3) Legitimated mobilization: network, discourse and opportunity should be able to consistently and deliberately realizeand deliver agreed environmental planning ideas, strategies, frameworks and policy outcomes.

\section{Reference}

Alexander, E. R. (1993). Interorganizational coordination: Theory and practice. Journal of Planning Literature, 7(4), 328-343.

Alexander, E. R. (2005). Institutional Transformation and Planning: From Institutionalization Theory to Institutional Design. Planning theory, 4(3), 209-223.

Amin, A., \& Thrift, N. (1994). Living in the global. In A. Amin \& N. Thrift (Eds.), Globalization, Institutions, and Regional Development in Europe (pp. 91-108). Oxford: Oxford University Press.

Bolan, R. S., Mandelbaum, S. J., Mazza, L., \& Burchell, R. W. (1996). Planning and the Institutional Design Explorations in Planning Theory (pp. 497-513). New Brunswick: Center for Urban Policy Research.

Booher, D. E., \& Innes, J. E. (2002). Network power in collaborative planning. Journal of Planning Education and Research, 21, 221-236.

Castell, M. (2003). The power of identity. Massachusetts: Blackwell.

Coaffee, J., \& Healey, P. (2003). 'My Voice: My Place': Tracking Transformations in Urban Governance. urban studies, 4O(10), 1979-1999.

Cohen, M. D., March, J. G., \& Olsen, J. P. (1972). A garbage can model of organizational choice. Administrative Science Quarterly, 17(1), 1-25.

Fischer, F., Forester, J., Fischer, F., \& Forester, J. (1993a). The Argumentative Turn in Policy Analysis and Planning. Durham: Duke University Press.

Fischer, F., Forester, J., Fischer, F., \& Forester, J. (1993b). Introduction The Argumentative Turn in Policy Analysis and Planning (pp. 1-17). Durham and London: Duke University Press.

Flyvbjerg, B. (1998). Rationality and Power: Democracy in Practice. Chicago: The University of Chicago Press.

Foucault, M. (1971). Orders of discourse: Inaugural lecture delivered at the College de France. Social Science Information, 10(2), 7-30.

Foucault, M. (1978). The history of sexuality volume 1: An introduction. New York: Phanteon Books.

Gamson, W. A. M., David S. (1996). Framing political opportunity. In D. M. McAdam, John D.; Zald, Mayer N. (Ed.), Comparative Perspectives on Social Movements: Political Opportunities, Mobilizing Structures, and Cultural Framings (pp. 274-290). Cambridge: Cambridge University Press.

Giddens, A. (1986). The Constitution of Society: Outline of the Theory of Structuration. Berkeley: University of California Press.

Gonzal,z, S., \& Healey, P. (2005). A Sociological institutionalist approach to the study of innovation in governance capacity. urban studies, 42(11), 2055-2069.

Grabher, G. (1993a). The Embedded Firm: On the Socioeconomics of Industrial Networks. London and New York: Routledge.

Grabher, G. (1993b). The weakness of strong ties: The lock-in of regional development in the Ruhr area. In G. Grabher (Ed.), The Embedded Firm: On the socioeconomics of Industrial Networks (pp. 255-277). London and New York: Routledge. 
Granovetter, M., \& Swedberg, R. (Eds.). (2001). The Sociology of Economic Life (Vol. Second Edition). Cambridge: Westview Press.

Granovetter, M. S. (1973). The strength of weak ties. The American Journal of Sociology, 78(6), 1360-1380.

Gualini, E. (2001). Planning and the Intelligence of Institutions: Interactive Approaches to Territorial PolicyMaking between Institutional design and Institution-Building. Aldershot: Ashgate.

Hajer, M. A. (1995). The Politics of Environmental Discourse: Ecological Modernisation and the Policy Process. Oxford: Clarendon Press.

Hajer, M. A., Brink, M. v. d., \& Metze, T. (2006). Doing Discourse Analysis: Coalitions, Practices, Meaning Words Matter in Policy and Planning: Discourse Theory and Method in Social Sciences (pp. 65-74). Utrecht: Netherlands Graduate School of Urban and Regional Research.

Hall, P. A., \& Taylor, R. C. R. (1996). Political science and the three institutionalisms. Political Studies, 44(4), 936-957.

Healey, P. (1997). Collaborative Planning, Shaping Places in Fragmented Societies. London: Macmillan.

Healey, P. (1998). Building institutional capacity through collaborative approaches to urban planning. Environment and Planning A, 30(9), 1531-1546.

Healey, P. (1999). Sites, jobs and portfolio: Economic development discourses in the planning system. urban studies, 36(1), 27-42.

Healey, P. (2007a). The new institutionalism and the transformative goals of planning. In N. Verma (Ed.), Institutions and Planning: Current Research in Urban and Regional Studies (pp. 61-88). Oxford: Elsevier.

Healey, P. (2007b). Urban Complexity and Spatial Strategy: Towards a relational planning for our times. New York: Routledge.

Hudalah, D., Winarso, H., \& Woltjer, J. (2007). Peri-urbanisation in East Asia: A new challenge for planning? International Development Planning Review, 29(4), 503-519.

Hudalah, D., Winarso, H., \& Woltjer, J. (forthcoming-a). Planning by opportunity: An analysis of peri-urban environmental conflicts in Indonesia. Environment and Planning $A$.

Hudalah, D., Winarso, H., \& Woltjer, J. (forthcoming-b). Policy networking as institutional capacity building: An analysis of regional road development conflict in Indonesia. Planning theory.

Hudalah, D., \& Woltjer, J. (2007). Spatial planning system in transitional Indonesia. International Planning Studies, 12(3), 291-303.

Hudalah, D., \& Woltjer, J. (2009). Constructing institutional capacity: The roles of discourse formation in the planning on the edge of Bandung City. Paper presented at the The 23rd Congress of the Association of European Schools of Planning (AESOP): Why can't the future be more like the past?, Liverpool.

Huxley, M., \& Yiftachel, O. (2000). New paradigm or old myopia? Unsettling the communicative turn in planning theory. Journal of Planning Education and Research, 19, 333-342.

Immergut, E. M. (1998). The theoretical core of the new institutionalism. Politics and Society, 26(1), 5-34.

Innes, J. E., \& Booher, D. E. (1999). Consensus building as role playing and bricolage: Toward a theory of collaborative planning. Journal of the American Planning Association, 66(6), 9-26.

Kingdon, J. W. (1984). Agendas, Alternatives, and Public Policies. Boston and Toronto: Little, Brown and Company.

Kitschelt, H. P. (1986). Political opportunity structures and political protest: Anti-nuclear movements in four democracies. British Journal of Political Science, 16(1), 57-85.

Koopmans, R. (1999). Political. Opportunity. Structure. Some splitting to balance the lumping. Sociological Forum, 14(1), 93-105.

Kriesi, H. K., Ruud; Duyvendak, Jan Willem; Giugni, Marco G. (1992). New social movements and political opportunities in Western Europe. European Journal of Political Research, 22(2), 219-244.

Lees, L. (2004). Urban geography: Discourse analysis and urban research. Progress in Human Geography, 28(1), 101-107.

Lowndes, V. (2001). Rescuing Aunt Sally: Taking Institutional Theory Seriously in Urban Politics. urban studies, 38(11), 1953-1971.

Lowndes, V. (2005). Something old, something new, something borrowed ... How institutions change (and stay the same) in local governance. Policy Studies, 26(3), 291 - 309.

McGuirk, P. M. (2000). Power and policy networks in urban governance: Local government and property-led regeneration in Dublin. Urban Studies, 37(4), 651-672.

McGuirk, P. M. (2001). Situating communicative planning theory: Context, power, and knowledge. Environment and Planning A, 33, 195-217. 
Moulaert, F., \& Cabaret, K. (2006). Planning, networks and power relations: is democratic planning under capitalism possible? Planning theory, 5, 51-70.

Powell, W. W. (1991). Neither market nor hierarchy: network forms of organization. In G. Thompson, J. Frances, R. Levacic \& J. Mitchel (Eds.), Markets, Hierarchies and Networks: The Coordination of Social Life (pp. 265-276). London: Sage Publications.

Powell, W. W., \& DiMaggio, P. J. (1991). The New Institutionalism in Organizational Analysis. Chicago: The University of Chicago Press.

Putnam, R. D. (1993). Making democracy work: Civic traditions in modern Italy. Princeton: Princeton University.

Richardson, T. (2002). Freedom and control in planning: Using discourse in the pursuit of reflexive practice. Planning Theory and Practice, 3(3), 353-361.

Richardson, T., \& Jensen, O. B. (2003). Linking discourse and space: Towards a cultural sociology of space in analysing spatial policy discourse. urban studies, 4Q(1), 7-22.

Rydin, Y. (1999). Can we talk ourselves into sustainability? The role of discourse in the environmental policy process. Environmental Values, 8, 467-484.

Rydin, Y. (2003). Conflict, Consensus, and Rationality in Environmental Planning: An Institutional Discourse Approach. Oxford: Oxforf University Press.

Tarrow, S. (1994). Power in Movement: Social Movements and Contentious Politics. Cambridge: Cambridge University Press.

Tarrow, S. (1996). States and opportunities: The political structuring of social movements. In D. M. McAdam, John D.; Zald, Mayer N. (Ed.), Comparative Perspectives on Social Movements: Political Opportunities, Mobilizing Structures, and Cultural Framings (pp. 41-61). Cambridge: Cambridge University Press.

Tewdwr-Jones, M., \& Allmendinger, P. (1999). Deconstructing communicative rationality: A critique of Habermasian collaborative planning. Environment and Planning A, 30(11), 1975-1989.

Throgmorton, J. A. (1992). Planning as persuasive storytelling about the future: Negotiating an electric power rate settlement in Illinois. Journal of Planning Education and Research, 12(1), 17-31.

Tilly, C. (1978). From Mobilization to Revolution. Reading: Addison-Wesley.

Uzzi, B. (1996). The sources and consequences of embeddedness for the economic performance of organizations: the network effect. American Sociological Review, 61(4), 674-698.

Vigar, G., Healey, P., Hull, A., \& Davoudi, S. (2000). Planning, Governance and Spatial Strategy in Britain: An Institutionalist Analysis. Houndmills: Macmillan.

Yeung, H. W.-c. (1994). Critical reviews of geographical perspectives on business organizations and the organization of production: towards a network approach. Progress in Human Geography, 18(4), 460490.

Zahariadis, N. (1999). Ambiguity, time, and multiple Streams. In P. A. Sabatier (Ed.), Theories of the Policy Process (pp. 73-93). Colorado: Westview Press. 